\title{
The presence of rare earth elements and critical metals in waste electric and electronic equipment: challenges for recovery
}

\author{
Sikander A. ${ }^{1,}{ }^{*}$, Savvilotidou V. ${ }^{2}$, Jia X. ${ }^{3}$ and Nicomel N. ${ }^{4}$ \\ ${ }^{1}$ Hamburg University of Technology, Institute of Environmental Technology and Energy Economics, Harburger Schloßstr. 36,21079 \\ Hamburg, Germany \\ ${ }^{2}$ Technical University of Crete, School of Environmental Engineering, University Campus, P.C. 73100, Chania, Crete, Greece \\ ${ }^{3}$ Technical University of Berlin, Department of Environmental Technology, Sekretariat Z 2, Straße des 17. Juni 135, 10623 Berlin, \\ Germany \\ ${ }^{4}$ Ghent University, Laboratory of Analytical Chemistry and Applied Ecochemistry, Coupure Links 653, B-9000 Gent, Belgium \\ Received: 11/01/2018, Accepted: 03/12/2018, Available online: 07/01/2019 \\ *to whom all correspondence should be addressed: e-mail: asma.sikander@tuhh.de \\ https://doi.org/10.30955/gnj.002582
}

\begin{abstract}
The fast growth of waste electric and electronic equipment (WEEE) is not only a threat to our environment, but also a great source of rare earth elements (REEs) and critical metals (CMs). Despite the fact that Directive 2012/19/EU encourages the treatment of WEEE by setting targets for collection, re-use and recycling, it does not directly target the recycling of REEs and CMs. The insufficient data about the composition of REEs and CMs in electric and electronic equipment (EEE), the high recycling costs and the different motivations/interests of the stakeholders are some of the main inhibiting factors. Recently, scientific community pays much attention to the recovery and recycling of REEs and CMs due to several associated benefits. Hence this work highlights the economic importance of REEs and CMs in terms of their inevitability in EEE. Then, an overview of the supply risk of REEs and CMs and the challenges related to the recovery are provided.
\end{abstract}

Keywords: WEEE recycling, supply risks, criticality risks, collection systems, losses of metals.

\section{Introduction}

A metal is labeled as critical when there is a risk of its scarcity and its availability, having simultaneously great economic and defensive importance for a country. The risk of supply may derive from political and economic conditions of the producing countries, difficulties in substitution and low recycling rates (European Commission, 2011). Specifically, REEs are not characterized as rare referring to their mineral depletion, but since their extraction through economically-feasible and environmentally-sound manner is troublesome taking into account both their low concentrations and also their attachment to other minerals (Hobohm et al., 2011). REE group consists of 17 chemical elements that are characterized by similar properties. Both REEs and CMs are found in a great number of applications. Miniaturization of electronics, empowerment of telecommunication, boost to renewable energy and improvement in medical and defense technologies are made possible due to these so-called "technology metals". Today, nearly $95 \%$ of REEs are produced in China (USGS, 2010). As nearly $40 \%$ of the world's rare earth oxides (REOs) reserves are located in China (USGS, 2014), it may be easily predicted that China will remain a dominant REEs supplier globally. This arises a great concern to have a reliable, sustainable, and legitimate access to these critical metals. Recycling, substitution, and resource efficiency are the remedies to tackle risk of supply by providing an alternative to primary production, which is not only strategic but also sustainable.

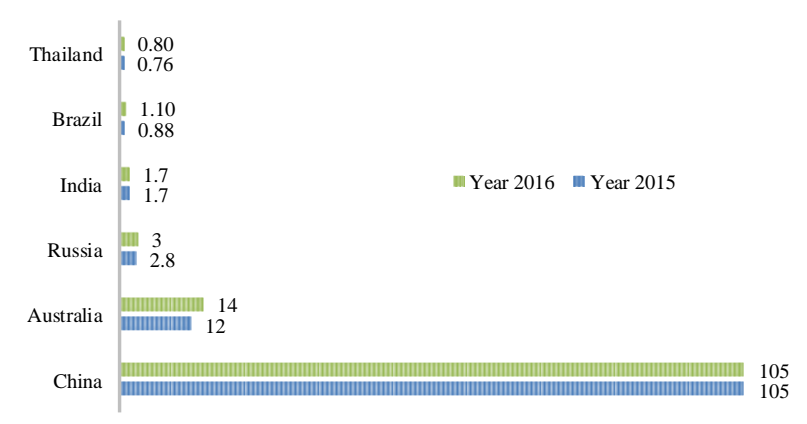

Figure 1. Top countries in RE mine production (in $10^{3}$ metric tons), (Investing News Network, 2016)

2. The economic importance of REEs and CMs and European dependency

Reliable and unhindered access to REEs is crucial for a country's economy. REEs market, which is considered as a "young" market is quite unpredictable. In the past the balance of demand and supply in the world market of REEs followed a wavy trajectory that started with extremely high prices between 2008 and 2011 and a dramatic $70 \%$ fall afterwards (Charalampides et al., 2015). 
European Union needs to import more than $90 \%$ of REEs from China (ERECON, 17/06/2015). Dearth of REEs does not only affect large economic value-added industries, but also many defense products and industries. As a result, whoever controls the supply side has the power to manipulate the prices. In 2015 and 2016, China's share in RE market decreased to $85.27 \%$ and $83.60 \%$, respectively. Other top RE production countries are Australia, Russia, India, Brazil and Thailand (Figure 1).

Prices of REEs are influenced by many internal and external factors. Internal issues may be the imbalance between demand and supply, the market trends, the customary assumptions etc. These factors have a short-time influence on prices, whereas external factors like economic growth of producing countries, policies and legislations, geopolitical situation, natural disaster etc. tend to induce long-term influence on prices. Variation in prices of selected rare earth oxides (REOs) are shown in Figure 2, indicating the price difference between year 2012 and 2016.

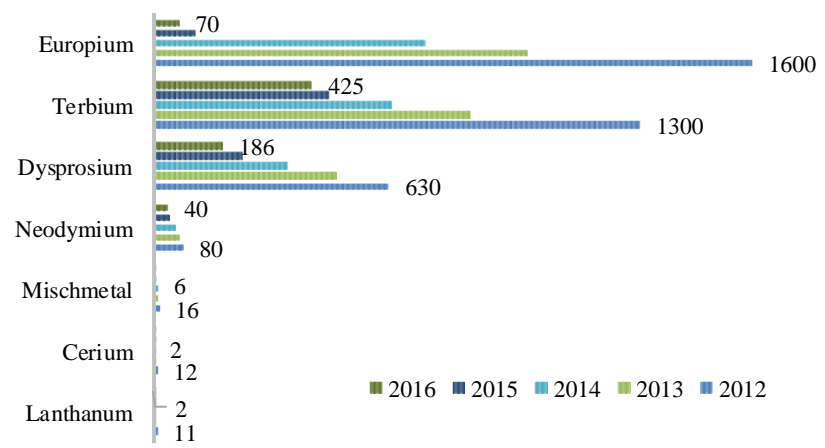

Figure 2. Evaluation of price of selected REOs (in USD $/ \mathrm{kg}$ ), (USGS Minerals Information, 2017)

Although the RE industry is currently in the maturity phase which means slowdown in the demand of RE raw material, at the same time the use of REEs in eco-friendly products like hybrid cars, wind mills, fuel cells and many other hi-tech industrial and consumer products are highly favored in Europe, predicting a considerable increase in demand of REEs in future.

\section{REEs and CMs use in EEE}

In order to focus on the secondary production of REEs and $\mathrm{CMs}$, it is vital to investigate their properties and their specific uses in EEE. The uses of REEs/CMs in EEE are too numerous to be listed but the major uses include permanent magnets for electric motors, advanced batteries, and phosphors for fluorescent lighting and display panels. The major end uses of light rare earth (LRE) and heavy rare earth (HRE) are listed in Table 1. It is clear that EEE has introduced a significant use of REEs and CMs required for manufacturing techniques.

\section{The risk of supply - challenges for REEs and CMs recovery}

Despite the high prices of REEs and CMs, a respective increase in their production has not yet been recorded. In fact, REEs and CMs are not the main products of mining operations, but "by-products" generated through the extraction of abundant base metals (Bakas et al., 2014). In parallel, the production of REEs and CMs from secondary resources, such as via recycling processes, remains very low due to the missing incentives with the focus mostly concentrated in other valuable materials. On this basis, the supply-demand interaction is not well-balanced. Taking into account that these metals are neither the main product in mining (primary production), nor in recycling or other activities (secondary production), REEs and CMs are almost "predestined" for the risk of supply. Therefore, the metal criticality is closely related to significant strategic/ technical or economic issues (Chanceler et al., 2016) and not derived from the limited ore deposits (Bakas et al., 2014). This phenomenon is called structural or technical scarcity.

Table 1. Selected end uses of REEs in EEE and other equipment (DOI, U.S. Geological Survey, Circular 930-N)

\begin{tabular}{|c|c|c|c|}
\hline LRE & $\begin{array}{l}\text { Major end } \\
\text { uses }\end{array}$ & HRE & $\begin{array}{c}\text { Major end } \\
\text { uses }\end{array}$ \\
\hline Lanthanum & $\begin{array}{c}\text { Hybrid } \\
\text { engines, } \\
\text { Phosphors }\end{array}$ & Terbium & $\begin{array}{c}\text { Permanent } \\
\text { magnets, } \\
\text { Phosphors }\end{array}$ \\
\hline Lutetium & $\begin{array}{l}\text { Catalysts in } \\
\text { petroleum } \\
\text { refining }\end{array}$ & Dysprosium & $\begin{array}{c}\text { Permanent } \\
\text { magnets, } \\
\text { hybrid } \\
\text { engines }\end{array}$ \\
\hline Praseodymium & $\begin{array}{l}\text { Permanent } \\
\text { magnets }\end{array}$ & Gadolinium & $\begin{array}{c}\text { Temporary } \\
\text { magnets }\end{array}$ \\
\hline Neodymium & $\begin{array}{l}\text { Auto catalyst, } \\
\text { hard drives in } \\
\text { laptops, } \\
\text { headphones, } \\
\text { hybrid } \\
\text { engines }\end{array}$ & Yttrium & $\begin{array}{c}\text { Red color, } \\
\text { fluorescent } \\
\text { lamps, } \\
\text { Phosphors }\end{array}$ \\
\hline Samarium & Magnets & Holmium & $\begin{array}{c}\text { Glass } \\
\text { coloring, } \\
\text { lasers }\end{array}$ \\
\hline Cerium & $\begin{array}{c}\text { Auto catalyst, } \\
\text { Phosphors }\end{array}$ & Thulium & $\begin{array}{c}\text { Medical X- } \\
\text { ray units }\end{array}$ \\
\hline Europium & $\begin{array}{l}\text { Red color for } \\
\text { television and } \\
\text { computer } \\
\text { screens, } \\
\text { phosphorus }\end{array}$ & & \\
\hline
\end{tabular}

The present work focused on the secondary production of REEs and CMs located in WEEE, which should be encouraged to bring both economic and environmental benefits in the frame of circular economy (Bakas et al., 2016). Chanceler et al. (2016) have reported concerns about the low concentrations located in the products and highlighted the gaps in the life cycle including the short useful time of products, then the insufficient collection of WEEE and the troublesome treatment chain. As a matter of fact, the insufficient infrastructures, the complex structure of this waste stream, the low concentrations of REEs and CMs used for highly specialized applications, the difficulties in scrap-metal recovery, the uncertainties of sales data, the export, as well as the adverse technical and 
economic limitations are the boundary conditions responsible for limited recycling of REEs and CMs (Binnemans et al., 2013). In spite of the aforementioned limitations, the recovery of REEs and CMs can offer significant reduction of $\mathrm{CO}_{2}$ emissions which are typically produced during the mining and refinery (Bakas et al., 2016; Hobohm et al., 2016; Cucchiella et al., 2015) and also reduction of REEs and CMs criticality (Savvilotidou et al., 2017; Hobohm et al., 2016). However, the recycling rate of REEs and CMs is less than 1\% (Binnemans et al., 2013). Therefore, the question is: what should be done to improve this recycling rate?

\section{Current situation of collection systems}

European Union has developed strategies and policies associated to critical raw materials in order to introduce the sustainable production, use and recycling of REEs and CMs. The core points needed optimization are (a) the technological development and innovation (e.g. sustainable supply, boosting recycling technologies), (b) the "raw materials diplomacy" (strong relations among countries, partnerships, stakeholders), (c) the higher education and training (to promote cooperation of professionals with scientific community), (d) the substitution of critical metals by less critical metals. No doubt the perspective for an efficient use of REEs and CMs including the mining operations, the refining, recycling and substitution generates great challenges (Chanceler et al., 2009). Focusing on WEEE recycling, there are three fundamental steps: collection, preprocessing and end-processing (Marra et al., 2015). Figure 3 illustrates the WEEE management step by step.

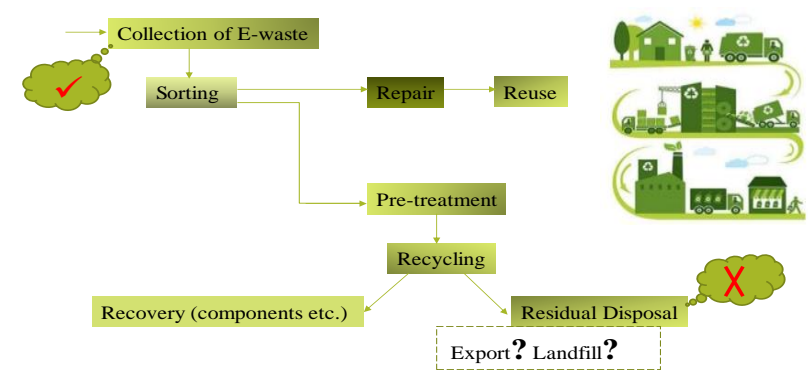

Figure 3. WEEE management procedures

To maximize the recovery quantities of REEs and CMs, it is better to start from the onset of the problem. According to Binnemans et al. (2013) and Hobohm et al. (2016), the inefficient collection (Ylä-Mella et al., 2014) is one of the main reasons for the low recycling rate. Directive on WEEE has established collection level of $65 \%$ wt. of the equipment placed on the market (POM) as an average of the three preceding years. Notably, in 2012 the WEEE collection rate was less than $50 \%$, while the average for the entire European Union had reached only 38\% (Król et al., 2016). The attitude of consumers (cultural-nationalsocial habits), the storage of WEEE in households, and the weak national take-back systems may play a key role which explains this low rate.
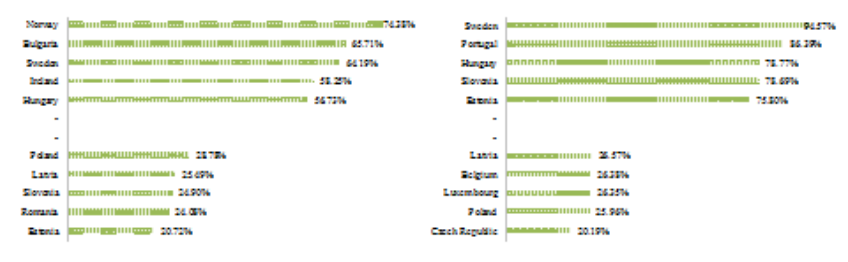

Figure 4. European countries with highest and lowest collection rate of large household appliances (left) and IT and

Telecommunication Equipment (right), (Eurostat, updated till March 2017)

\subsection{Collection of WEEE in Europe}

According to Eurostat (2017), among European countries, the collection rate of WEEE varies significantly. Figure 4 presents the European countries with highest and lowest collection rate for large household appliances (left) and IT and Telecommunication Equipment (right). Studies show that Scandinavian territories (such as Norway, Sweden etc.) have managed high collection rates by achieving well-developed systems for waste handling and treatment (Baxter et al., 2016). This is also confirmed in Figure 4, since Norway has the highest collection rate of large household appliances of approximately $74.38 \%$. Regarding IT and Telecommunications equipment, 5 countries can achieve collection rate higher than $75 \%$. However, there are also 5 countries reaching rate lower than $30 \%$.

Looking forward to deal with the future criticality risks, some recommendations and potential solutions should be introduced among which (1) technological innovation, (2) strong legislation, (3) improvement of the data reliability and (4) new initiatives are the most important. To the author's best knowledge, prior to any attempt, responsibilities should be addressed to the closely associated parties, as mentioned in Figure 5.

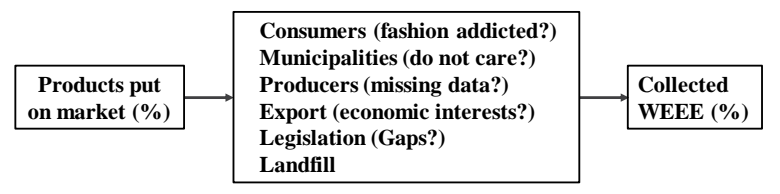

Figure 5. Parties with responsibility in WEEE collection

It is crucially important to determine the real percentage of products put on market, and then to identify the losses driving to low collection rates. In Figure 6, the data presented are related to the annual amount of products put on market and the respective collection rate from 2006 to 2014. It is revealed that the collection rate has been increasing, but not enough.

With respect to higher collection rates, among the promising perspectives recommended to member states is to provide attractive incentives for critical metals-rich product groups collection. In specific terms, although legislation addresses WEEE as a uniform waste stream, if product groups with high concentrations of critical metals are promoted for separate collection, the smelters would probably benefit from the economic 
aspects, as well as from the simpler processing of such a sub-stream (Moss et al., 2011).

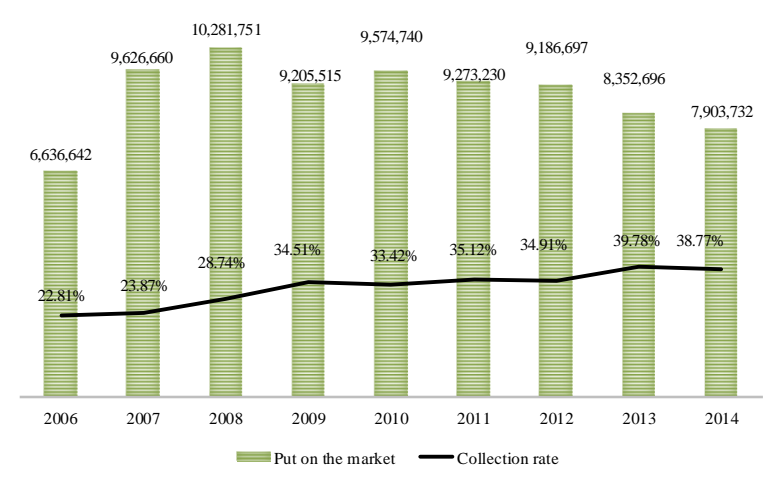

Figure 6. Amount of EEE put on the market (in tons) and Collection rate in European Union (Eurostat, updated till March 2017)

\section{Conclusions}

Nowadays, rare earth metals and critical metals are used in a wide range of electronic products. With this, the supply risk of these metals will significantly increase considering the growing demand for more advanced technologies, as well as the shorter lifespan of EEE in the market. To compensate the supply of these metals, WEEE can act as a secondary resource of REEs and CMs. This has already been acknowledged through numerous research calls released by the European Union. To make sure that WEEE could be a part of the solution to the risk of supply of REEs and CMs, sustainable management of these wastes should be given significant attention. This can be done by improving practices dealing with the various steps from production to consumption, repair and remanufacturing, waste management and secondary raw materials fed back into the economy. This calls for more complete and stricter WEEE legislations and the formulation of corresponding policies and regulations. Economic incentives for bringing WEEE into the circular economy should be developed and promoted. Moreover, if material recovery will be targeted, it is important that this is already considered in the design and manufacturing processes of EEE. Eco-design, cost-effective, and environmentally friendly production concepts should be introduced into EEE industry to meet the terms of the legislations. As a final point, public awareness regarding environmental protection should also be advocated. It is time that universities, governments, organizations, and companies work together to change the outlook of the public on the end-of-life EEE.

\section{Acknowledgement}

The authors are thankful to COST Action ES1407 ReCreew program and Prof. Kerstin Kuchta's inspiration and her encouragement on this paper.

\section{References}

Bakas I.C., Herczeg M.C., Vea E.B.C., Fråne A.I., Youhanan L.I. and Baxter J.Ø. (2016), Critical Metals in Discarded Electronics: Mapping Recycling Potentials from Selected Waste Electronics in the Nordic Region, Nordic Council of Ministers.

Baxter J., Lyng K.A., Askham C. and Hanssen O.J. (2016), Highquality collection and disposal of WEEE: Environmental impacts and resultant issues, Waste Management, 57, 17-26.

Binnemans K., Jones P.T., Blanpain B., Van Gerven T., Yang Y., Walton A. and Buchert M. (2013), Recycling of rare earths: a critical review, Journal of Cleaner Production, 51, 1-22.

Chancerel P., Meskers C.E., Hagelüken C. and Rotter V.S. (2009), Assessment of precious metal flows during preprocessing of waste electrical and electronic equipment, Journal of Industrial Ecology, 13(5), 791-810.

Chancerel P., Meskers C.E., Hagelüken C., Rotter V., Hobohm J., Kuchta K., Krüger O., van Wasen S. and Adam C. (2016), Optimized elemental analysis of fluorescence lamp shredder waste, Talanta, 147, 615-620.

Charalampides G., Vatalis K.I., Baklavaridis A. and Benetis P. (2015), Industrial Applications and Economic Dependency of Europe, International Conference on Applied Economics (ICOAE) 2015 Rare Earth Elements.

Cucchiella F., D'Adamo I., Koh S.L. and Rosa P. (2015), Recycling of WEEEs: An economic assessment of present and future ewaste streams, Renewable and Sustainable Energy Reviews, 51, 263-272.

DOI U.S. (1997), Geological Survey, Circular 930-N, http://doczz. $\mathrm{nl} /$ doc/127340/doi--us-geological-survey--circular-930-n (accessible on 03.04.2017).

ERECON, (17/06/2015), Strengthening the European Rare Earth Supply-Chain. Challenges and policy options. http://ec.europa.eu/DocsRoom/documents/10882/attachm ents/1/translations.

European Commission (2011), Tackling the Challenges in Commodity Markets and on Raw Materials (Brussels).

Eurostat (2017), updated till March 2017, available at: http://ec.europa.eu/eurostat/statistics-explained/index.php /Waste_statistics_-_electrical_and_electronic_equipment (accessible on 03.04.2017).

Hobohm J., Kuchta K., Krüger O., van Wasen S. and Adam C. (2016), Optimized elemental analysis of fluorescence lamp shredder waste, Talanta, 147, 615-620.

Investing News Network (2017), available at: http://investingnews.com/critical-metalsinvesting/(accessible on 03.04.2017).

Król A., Nowakowski P. and Mrówczyńska B. (2016). How to improve WEEE management? Novel approach in mobile collection with application of artificial intelligence, Waste Management, 50, 222-233.

Marra A., Cesaro A. and Belgiorno V. (2015), WEEE Mechanical Treatments: Recovery Effectiveness of Critical Materials, Proceedings of the 14th International Conference on Environmental Science and Technology. Rhodes, Greece, 3-5 September 2015.

Moss R.L., Tzimas E., Kara H., Willis P. and Kooroshy J. (2011), Critical Metals in Strategic Energy Technologies, JRCscientific and strategic reports, European Commission Joint Research Centre Institute for Energy and Transport. 
Savvilotidou V., Antoniou A. and Gidarakos E. (2017), Toxicity assessment and feasible recycling process for amorphous silicon and $\mathrm{CIS}$ waste photovoltaic panels, Waste Management, 59, 394-402.

USGS Minerals Information (2017), available at: https://minerals.usgs.gov/minerals/pubs/commodity/rare_e arths/mcs-2017-raree.pdf (accessible on 03.04.2017).

USGS (2010), Mineral commodity summaries 2010, https://minerals.usgs.gov/minerals/pubs/mcs/2010/mcs201 0.pdf (accessible on 03.04.2017).

USGS (2014), Mineral commodity summaries 2010, https://minerals.usgs.gov/minerals/pubs/mcs/2014/mcs201 4.pdf (accessible on 03.04.2017).

Ylä-Mella J., Poikela K., Lehtinen U., Keiski R.L. and Pongrácz E. (2014), Implementation of Waste Electrical and Electronic Equipment Directive in Finland: Evaluation of the collection network and challenges of the effective WEEE management, Resources, Conservation and Recycling, 86, 38-46. 